\title{
Cultural Globlization
}

and Its Impacts on Students

in Socio-Economically Backward District Bhakkar

of Pakistan During $21^{\text {st }}$ Century

\author{
Syed Raheem Abbas ${ }^{\mathrm{a}}$ and Muhammad Asim ${ }^{\mathrm{b} *}$ \\ ${ }^{a}$ College Bhakkar \\ Pakistan \\ ${ }^{b}$ College Asghar Mall, Rawalpindi \\ Pakistan
}

Received 20.01.2015, received in revised form 09.02.2015, accepted 26.04.2015

Globalization is currently an important wonders subjecting on economic activities, socio-cultural element, political aspect and so on. This paper is made mainly on cultural changes directing the impact on moral issue and lifestyle in the Pakistan and particularly Government College Bahkkar, University of Sargodha students. The study finds the domination of Western culture on all lives that wear away cultural heritage and moral values. There has been creating consumerism by which western lifestyles are on diffusion. The specific objective of the study is to analyze how globalization rapidly transforms the social values and living pattern in the traditional societies in Bahkkar students. There have been some negative aspects; but modernization process is positively functioning as well. Most of the data is mainly collected from two institutions; government college Bhakkar and University of Sargodha Bhakkar Campus sources. The study findings would be helpful for the Bhakkar students to be aware of cultural hybridization in the age of globalization. It is thought that some new ideas and information may be added into social sciences.

Keywords: Cultural Hybridization, Bhakkar, Western Culture, Moral Values, Lifestyle, Erosion, McDonald's, Cultural Heritage.

This information is received by an interview with Riaz Ahmad, Statistical Officer, Statistics Department, Bhakkar.

DOI: 10.17516/1997-1370-2015-8-11-2152-2161.

Research area: politology, economics.

\section{Research Methodology}

This study is based on theoretically and historically descriptive, analytical, comparative and qualitative methods. The data is collected from books, research journals, newspapers, internet, interviews, results of different dissertations, and personal visit of university campus and government postgraduate college in Bhakkar. A questionnaire was also designed for measuring Globalization of culture patterns and its impacts

(c) Siberian Federal University. All rights reserved

* Corresponding author E-mail address: raheemshahbk786@gmail.com, Asimsheikh62@yahoo.com 
on Bhakkar that was analyzed through statistical formulas.

\section{Introduction}

Fast changes are seeing at cultural level, as a result of increasing globalization and reforms in the third world countries in recent times. It is also experiential that culture is being changed rapidly from late 90s. Though its changing process started just after World War II, western culture controls over the rest of the world since early in twentieth century. This is presently observed that it has been one kind of cultural domination which mainly based on capitalism. The prominent popular American i.e. Western cultural symbols such as Coca-Cola, blue jeans, rock music and McDonald's Golden Bends are getting spread all over. Gradually, the world is transforming into a single global culture. According to Tomlinson (1991), such cultural merging represents a form of dominate that will destroy cultural variety. In this sense, cultural globalization possesses a threat to nation states. Behavioral pattern and lifestyles in Bhakkar gets a new form influenced by Western culture. There was a different pattern of its food, dress, custom, manner, value for a long time. But in a couple of decades there is a visible change in all the matters. Fast food, T-shirt, Jeans, soft drinks have been now the integral part of young generation. Cultural custom is on eroding trends by Western world. There are some positive impacts globalizations on lives, but negative impacts are sharply bigger in these changes. The negatives are reproduced on the rising trend of cultural violence, armed reactions to cultural imperialism and increasing dominance of a customer and selforiented society, leading to loss of spiritual and community oriented values worldwide (Parker, 2005a:218).

Bhakkar is a southern district in the Punjab province of Pakistan. It assumed the status of district in 1982, with Bhakkar city as its capital, word, originally taken from Thalochi dialect of Punjabi language. The major part of the district consists in the desolate arid zone of the desert, Thal. But, however the long strip of the land along the river Indus is very rich and fertile. Historically, the remainder of the district comprising the Indus basin, is called Chol-e-Jalali.

Mankera is supposed to be the middle of the great Thal. It is presumably a place of antiquity and is believed to be a historical heritage. It is right to add that, among these large stretches of sand, the historic and historical places of this region need to be preserved. Some of the historians even regard Kallurkot to be an old place located in the western Punjab. The town has some historical places like Dilkusha Bagh (a garden) which is believed to be a Mughal era .It may seem remarkable the golden garden is associated with great empire of Mughal, Humayun.

The old town was walled and had virtually gates such as Tavela gate and Imamanwala gate. The only remaining gate Jinnah Gate (formerly King Gate) was built in British period in the name of Mr. King the then Deputy Commissioner. There are remains of a Handera (tomb) near Sheikh Rao Bridge, which is believed to be burial place of Bakhar Khan, the founder of the city. Some 30 years ago a branch of River Indus flowed past the town. West side of the town was green and pleasant.

The main city center comprises Mundi Town, King gate (markets and shopping centers), Chimni Mohalla (ancient area ever in Bhakkar city from past of the Hindus and Sikh residency), Gulshan-e-Madina Town, Officers Colony, Canal Avenue, new developed Green Town, Dhandla Mohalla, Mohallah Jafria, Gadola, and Aalam Abad. The adjacent city area Mundi Town is the developed residential area having modern facilities. 
The population speaks Urdu, Punjabi and Seraiki. Bhakkar is becoming famous by its quality of education. The teachers pay full attention to their taught without any material consideration. The students showed good results. They manage to get top positions in respective board and universities, irrespective of the fact that they have meager recourses at hand. Trade, commerce and industry are in desperate conditions. Development sectors, including social and economic are not rather satisfactory and the people in general suffer and harbor grievances against the politicians. The shining students make their way to Lahore, Sargodha, Faisalabad and Multan. The business in the city is major source of income for the population and mostly business activities are connected with Capital of Province, Lahore. In Bhakkar, socio-political violence, communal conflict, murder, women repression, changes of values and lifestyles have been a great energy to the people of all walks. The study has been selected on the concerned of this cultural conflict and transformation in Bhakkar.

\section{Socio-Cultural Activities in District Bhakkar}

Population of any region is important because all the elements of the area revolve around it. After it ,the land and the geographical status of the area are very much important.

It's geographical status of affairs play an important and prominent role in determining its place, status and importance in a region there the population and its land play important role in its political ,social and economic development The population of district Bhakkar is scattered in all the parts of the district.

The major population of the district is consist of in four cities, Bhakkar city the district headquarters, Darya khan (tehsil headquarters) Kallur kot (tehsil headquarters) and Mankera (tehsil headquarters).The major population reside in Bhakkar city. However the following towns are also populous. Hyderabad, Behal, Notak, Jandanwala, Dullewala and Kotla jam.

According to the census report of 1998 and statistical assessment of 2008 following is the chart of population of district Bhakkar:

\begin{tabular}{|l|c|c|c|c|}
\hline \multicolumn{1}{|c|}{ Area } & Both sexes & Male & Women & Growth Rate \\
\hline District Bhakkar & & & & \\
\hline 1998 & $1,051,456$ & 543,661 & 507,795 & \\
\hline 2008 & 1354570 & 724,661 & 629,909 & 2.72 \\
\hline Tehsil Bhakkar & & & & \\
\hline 1998 & 424,488 & 219,038 & 205,450 & \\
\hline 2008 & 550,339 & 293,469 & 256,870 & 2.80 \\
\hline Tehsil Mankera & & & & \\
\hline 1998 & 169,888 & 87,970 & 81,912 & \\
\hline 2008 & 219,846 & 113,897 & 105,949 & 2.70 \\
\hline Tehsil Darya Khan & & & & \\
\hline 1998 & 233,410 & 121,303 & 112,107 & \\
\hline 2008 & 301,440 & 156,993 & 144,455 & 2.76 \\
\hline Tehsi Kallur kot & & & & \\
\hline 1998 & 223,676 & 115,350 & 108,326 & \\
\hline 2008 & 282,945 & 146,444 & 136,501 & 2.49 \\
\hline
\end{tabular}


The linguistic expert considers the language spoken in Bhakkar as a dialect of the North. This dialect was named Seraiki by the people of the Indus civilization. In the Sindhi language the word sero" means the diamond. This word is alsoused forshumal or ubha (the North). The language Seraiki is perhaps as old as one lac and ten thousands yeas.

With the regard to the evolution, the Seraiki language the linguistic experts believe that this was the language of the Asuri people, who before the arrival of the Arians, came to Baluchistan and then settled in different areas of Multan and Sindh.

The society of Bhakkar has been a narrow minded and backward one. The place ofwomen has always been a victim of degradation. The attitude towards women has alsobeen tinged with narrow mindedness.

The females of the Bhakkar had remained target of cruelty, the birth day of female child is taken as a bad omen on her birth a gloomy wave engulfed the whole family and all relatives and friends specially come to console the family. The birth day of male child is celebrated warmly while mourning is made on birthday of a female one. In homes sons are treated distinctively even in distribution of food, sons are preferred to the daughters. High level edibles were given to the boys but girls were provided with lower food.

Co-existence with Hindus impact negative impression on resident of Bhakkar and so they begin to treat her like man s shoe. She is treated as like a slave and she is forced to follow all the orders of the giant. She is deprived of the right of property. She is abused by the husband and is deprived of the right of education, forced labor without wages is taken from her in fields and many other types of oppressions are applied against her. Now condition is being changed due to education and awareness. The position and value of women is being raised and is being provided with right of education. She is now being considered as the beauty of a home, instead of shoe of feet. But still there is capacity for improvement and women in many back ward families are being treated with tyranny.

\section{Literature Review}

A good number of books and articles have been reviewed to collect required data and to prove the importance of Selecting the study. These are: Cultural Imperialism, by Jhon Tomlinson (1991). Globalization and culture, by Jhon Tomlinson (1999).

Globalization, Governance Reforms and development: An Introduction, by kameshwar Choudhary (2007). The Islamic Conception of justice, by M. Khadduri and so on.Two articles have also been studied such as: By reviewing 'Globalization and Culture', by Girish Mishra (2004), it is found that changes of lifestyle domain and Indian cultural issues have been focused; but moral values in the age of globalization didn't get priority at all. In 'Globalization and the Moral Issue' by V.V.Maliavin (2012), these are seen that moral status, modernity, humanism and spiritualism were mostly emphasized; but changes of lifestyle pattern could not be highlighted. There was no sufficiently organized and analytical work found on the region. Some very little works by Noor Muhammad Thind (Taarrekh-e-Bhakkar), (Auliyai-e- Bhakkar), Dr. Aslam Niazi (Taarrekh-e- Mianawali), Munshi Churnjeet (Tawareekh-e-Dera Ismail Khan), Munshi Abdul Rehman (Tarreekh-eMultan), Noor Muhammad Thind (Tarreekhe-Layyah), Dost Muhammad (Tarreekh-eMankera) presented only basic information about some part of the region. But no paper work is ever done on this core issue, so this work will proved to be the first of its kind. 


\section{Sample}

The sample of the study $(\mathrm{N}=100)$ consisted of Master Degree programs from two institutions, one postgraduate college and one Sargodha University sub campus Bhakkar, Most of the study was mainly belonged to the disciplines of Political Science, Sociology, Urdu and English. A sample of 50 students was taken from the Sargodha University Sub Campus while same number of sample was taken by Government Postgraduate College Bhakkar. Discipline wise, there are 50 students of M.Sc Sociology in which 29 are male and 21 are female, 22 students of M.A Political Science in which 10 are male and 12 are female, 20 students of M.A English which are all females, and, 8 students of M.A Urdu in which 3 are male and 5 are.

\section{Instrument}

A questionnaire is designed for measuring impacts of global cultural patterns on the postgraduate students of Bhakkar district according to gender wise, institution wise and subject wise. All the 11 questions given in the questionnaire provide an option of YES and NO to the students.

\section{Results}

The following tables are giving the results as per each question according to institution wise, gender wise and subject wise.

Question No:01

\begin{tabular}{|l|c|c|c|c|c|c|c|c|}
\hline \multicolumn{8}{|c|}{ Do you agree that foreign channels (cable TV channels) invading our cultural values? } \\
\hline \multirow{5}{*}{} & $\begin{array}{c}\text { Sargodha University } \\
\text { Sub Campus Bhakkar }\end{array}$ & \multicolumn{7}{c|}{ Government Postgraduate College Bhakkar } \\
\cline { 2 - 10 } & MSc Sociology & M.A English & \multicolumn{2}{c|}{ M.A Urdu } & \multicolumn{2}{c|}{ M.A Political Science } \\
\cline { 2 - 10 } & YES & NO & YES & NO & YES & NO & YES & NO \\
\hline Male & 29 & 0 & 0 & 0 & 3 & 0 & 10 & 0 \\
\hline Female & 21 & 0 & 20 & 0 & 5 & 0 & 12 & 0 \\
\hline Total & 50 & 0 & 20 & 0 & 8 & 0 & 22 & 0 \\
\hline
\end{tabular}

Note: All the male and female students from both the institutions said "YES" in response of this statement.

Question No:02

\begin{tabular}{|l|c|c|c|c|c|c|c|c|}
\hline \multicolumn{1}{|c|}{ Do you agree that we are going to adopt the global culture? } \\
\hline & $\begin{array}{c}\text { Sargodha University } \\
\text { Sub Campus Bhakkar }\end{array}$ & \multicolumn{2}{c|}{ Government Postgraduate College Bhakkar } \\
\cline { 2 - 10 } & MSc Sociology & \multicolumn{2}{c|}{ M.A English } & \multicolumn{2}{c|}{ M.A Urdu } & \multicolumn{2}{c|}{ M.A Political Science } \\
\cline { 2 - 10 } & YES & NO & YES & NO & YES & NO & YES & NO \\
\hline Male & 27 & 2 & 0 & 0 & 2 & 1 & 8 & 2 \\
\hline Female & 15 & 6 & 20 & 0 & 5 & 0 & 12 & 0 \\
\hline Total & 42 & 8 & 20 & 0 & 7 & 1 & 20 & 2 \\
\hline
\end{tabular}

Note: $89 \%$ students are agreed with this statement while $11 \%$ refuse to accept this point. 
Question No:03

\begin{tabular}{|l|c|c|c|c|c|c|c|c|}
\hline \multicolumn{8}{|c|}{ Can Pakistani culture heritage serve as unifying culture? } \\
\hline & $\begin{array}{c}\text { Sargodha University } \\
\text { Sub Campus Bhakkar }\end{array}$ & \multicolumn{7}{c|}{ Government Postgraduate College Bhakkar } \\
\cline { 2 - 9 } & MSc Sociology & \multicolumn{2}{c|}{ M.A English } & \multicolumn{2}{c|}{ M.A Urdu } & \multicolumn{2}{c|}{ M.A Political Science } \\
\cline { 2 - 9 } & YES & NO & YES & NO & YES & NO & YES & NO \\
\hline Male & 28 & 1 & 0 & 0 & 2 & 1 & 8 & 2 \\
\hline Female & 21 & 0 & 20 & 0 & 5 & 0 & 12 & 0 \\
\hline Total & 49 & 1 & 20 & 0 & 7 & 1 & 20 & 2 \\
\hline
\end{tabular}

Note: $96 \%$ students consider Pakistani culture heritage as unifying culture but $4 \%$ did not agree with this statement.

Question No:04

\begin{tabular}{|l|c|c|c|c|c|c|c|c|}
\hline \multicolumn{8}{|c|}{ Do you agree that Pakistani culture heritage has ability to be globalized? } \\
\hline \multirow{5}{*}{} & $\begin{array}{c}\text { Sargodha University } \\
\text { Sub Campus Bhakkar }\end{array}$ & \multicolumn{7}{c|}{ Government Postgraduate College Bhakkar } \\
\cline { 2 - 9 } & MSc Sociology & \multicolumn{2}{c|}{ M.A English } & \multicolumn{2}{c|}{ M.A Urdu } & \multicolumn{2}{c|}{ M.A Political Science } \\
\cline { 2 - 9 } & YES & NO & YES & NO & YES & NO & YES & NO \\
\hline Male & 29 & 0 & 0 & 0 & 3 & 0 & 7 & 3 \\
\hline Female & 21 & 0 & 20 & 0 & 5 & 0 & 12 & 0 \\
\hline Total & 50 & 0 & 20 & 0 & 8 & 0 & 19 & 3 \\
\hline
\end{tabular}

Note: just $3 \%$ instead of $97 \%$ think that Pakistani culture heritage has no ability to be globalized.

Question No:05

\begin{tabular}{|l|c|c|c|c|c|c|c|c|}
\hline \multicolumn{8}{|c|}{ Do you agree that you can communication easily with others without mobile? } \\
\hline & $\begin{array}{c}\text { Sargodha University } \\
\text { Sub Campus Bhakkar }\end{array}$ & \multicolumn{7}{c|}{ Government Postgraduate College Bhakkar } \\
\cline { 2 - 9 } & MSc Sociology & \multicolumn{2}{c|}{ M.A English } & \multicolumn{2}{c|}{ M.A Urdu } & \multicolumn{2}{c|}{ M.A Political Science } \\
\cline { 2 - 9 } & YES & NO & YES & NO & YES & NO & YES & NO \\
\hline Male & 25 & 4 & 0 & 0 & 3 & 0 & 10 & 0 \\
\hline Female & 18 & 3 & 20 & 0 & 5 & 0 & 12 & 0 \\
\hline Total & 43 & 7 & 20 & 0 & 8 & 0 & 22 & 0 \\
\hline
\end{tabular}

Note: $93 \%$ students say that they can communicate with others without mobile but $7 \%$ consider it as an essential source of communication. 
Question No: 06

\begin{tabular}{|l|c|c|c|c|c|c|c|c|}
\hline \multicolumn{6}{|c|}{ Do you agree that information can collect more easily on social media than the newspapers or magazine? } \\
\hline \multirow{5}{*}{} & $\begin{array}{c}\text { Sargodha University } \\
\text { Sub Campus Bhakkar }\end{array}$ & \multicolumn{7}{c|}{ Government Postgraduate College Bhakkar } \\
\cline { 2 - 10 } & MSc Sociology & \multicolumn{2}{c|}{ M.A English } & \multicolumn{2}{c|}{ M.A Urdu } & \multicolumn{2}{c|}{ M.A Political Science } \\
\cline { 2 - 9 } & YES & NO & YES & NO & YES & NO & YES & NO \\
\hline Male & 29 & 0 & 0 & 0 & 3 & 0 & 10 & 0 \\
\hline Female & 21 & 0 & 20 & 0 & 5 & 0 & 12 & 0 \\
\hline Total & 50 & 0 & 20 & 0 & 8 & 0 & 22 & 0 \\
\hline
\end{tabular}

Note: All the male and female students of both the institutions are agreed with the statement.

Question No: 07

\begin{tabular}{|l|c|c|c|c|c|c|c|c|}
\hline \multicolumn{4}{|c|}{ Do you agree that English must learn to survive in the globalized world? } \\
\hline & $\begin{array}{c}\text { Sargodha University } \\
\text { Sub Campus Bhakkar }\end{array}$ & \multicolumn{7}{c|}{ Government Postgraduate College Bhakkar } \\
\cline { 2 - 10 } & MSc Sociology & \multicolumn{2}{c|}{ M.A English } & \multicolumn{2}{c|}{ M.A Urdu } & \multicolumn{2}{c|}{ M.A Political Science } \\
\cline { 2 - 10 } & YES & NO & YES & NO & YES & NO & YES & NO \\
\hline Male & 29 & 0 & 0 & 0 & 3 & 0 & 10 & 0 \\
\hline Female & 21 & 0 & 20 & 0 & 5 & 0 & 12 & 0 \\
\hline Total & 50 & 0 & 20 & 0 & 8 & 0 & 22 & 0 \\
\hline
\end{tabular}

Note: Note: All the male and female students of both the institutions are agreed with the statement.

Question No: 08

\begin{tabular}{|l|c|c|c|c|c|c|c|c|}
\hline \multicolumn{8}{|c|}{ Do you use words of English language during speaking your local language? } \\
\hline & $\begin{array}{c}\text { Sargodha University } \\
\text { Sub Campus Bhakkar }\end{array}$ & \multicolumn{7}{c|}{ Government Postgraduate College Bhakkar } \\
\cline { 2 - 9 } & MSc Sociology & \multicolumn{2}{c|}{ M.A English } & \multicolumn{2}{c|}{ M.A Urdu } & \multicolumn{2}{c|}{ M.A Political Science } \\
\cline { 2 - 9 } & YES & NO & YES & NO & YES & NO & YES & NO \\
\hline Male & 29 & 0 & 0 & 0 & 3 & 0 & 10 & 0 \\
\hline Female & 21 & 0 & 20 & 0 & 5 & 0 & 11 & 1 \\
\hline Total & 50 & 0 & 20 & 0 & 8 & 0 & 21 & 1 \\
\hline
\end{tabular}

Note: $99 \%$ students use different words of English language during speaking their local language. 
Question No: 09

\begin{tabular}{|l|c|c|c|c|c|c|c|c|}
\hline \multicolumn{8}{|c|}{$\begin{array}{r}\text { Do you agree that our educational instructions must be in English } \\
\text { to get international standards of higher education? }\end{array}$} \\
\hline & $\begin{array}{c}\text { Sargodha University } \\
\text { Sub Campus Bhakkar }\end{array}$ & \multicolumn{7}{c|}{ Government Postgraduate College Bhakkar } \\
\cline { 2 - 10 } & MSc Sociology & M.A English & M.A Urdu & \multicolumn{2}{c|}{ M.A Political Science } \\
\cline { 2 - 10 } & YES & NO & YES & NO & YES & NO & YES & NO \\
\hline Male & 29 & 0 & 0 & 0 & 1 & 2 & 10 & 0 \\
\hline Female & 20 & 1 & 20 & 0 & 1 & 4 & 12 & 0 \\
\hline Total & 49 & 1 & 20 & 0 & 2 & 6 & 22 & 0 \\
\hline
\end{tabular}

Note: $7 \%$ instead of $93 \%$ did not agree with this statement that educational instructions must be in English language to get international standards of higher education.

Question No: 10

\begin{tabular}{|l|c|c|c|c|c|c|c|c|}
\hline \multicolumn{8}{|c|}{$\begin{array}{c}\text { Do you agree that Pakistan must remain an Islamic republic } \\
\text { when it is facing huge sectarian differences and religious military? }\end{array}$} \\
\hline & $\begin{array}{c}\text { Sargodha University } \\
\text { Sub Campus Bhakkar }\end{array}$ & \multicolumn{7}{c|}{ Government Postgraduate College Bhakkar } \\
\cline { 2 - 10 } & MSc Sociology & M.A English & M.A Urdu & \multicolumn{2}{c|}{ M.A Political Science } \\
\cline { 2 - 10 } & YES & NO & YES & NO & YES & NO & YES & NO \\
\hline Male & 4 & 25 & 0 & 0 & 1 & 2 & 1 & 9 \\
\hline Female & 15 & 6 & 0 & 20 & 0 & 5 & 3 & 9 \\
\hline Total & 19 & 31 & 0 & 20 & 1 & 7 & 4 & 18 \\
\hline
\end{tabular}

Note: $76 \%$ did not agree that Pakistan should be an Islamic Republic when it is facing huge sectarian differences and religious militancy while, $24 \%$ said that Pakistan should remain an Islamic Republic.

Question No: 11

Do you agree with this statement that Jeans shirt makes a person more active and shalwar kamiz becomes a person lazy?

\begin{tabular}{|l|c|c|c|c|c|c|c|c|}
\hline & \multicolumn{7}{|c|}{$\begin{array}{c}\text { Sargodha University } \\
\text { Sub Campus Bhakkar }\end{array}$} & \multicolumn{6}{|c|}{ Government Postgraduate College Bhakkar } \\
\cline { 2 - 9 } & \multicolumn{2}{|c|}{ MSc Sociology } & M.A English & \multicolumn{2}{c|}{ M.A Urdu } & \multicolumn{2}{c|}{ M.A Political Science } \\
\cline { 2 - 9 } & YES & NO & YES & NO & YES & NO & YES & NO \\
\hline Male & 0 & 29 & 0 & 0 & 0 & 3 & 2 & 8 \\
\hline Female & 0 & 21 & 0 & 20 & 0 & 5 & 2 & 10 \\
\hline Total & 0 & 50 & 0 & 20 & 0 & 8 & 4 & 18 \\
\hline
\end{tabular}

Note: $96 \%$ did not agree with this statement instead of $4 \%$ 


\section{Recommendations}

It is recommended that globalization touches all human lives and plays strong role in transformation of moral values and lifestyles in Bhakkar. The process brings some opportunities; but its root challenges for the poor nations are the horrible matters as well. Advantages of globalization process have to be availed by overcoming the problems. No Pakistani including Bhakkar individually are able to attain desired wellbeing without fighting the challenges of globalization because of its collective manner. Without negotiating skill, thoughtful diplomacy, technology transfer, proper policy management, human resource and so on, no country avail the global opportunity. The policy makers can be helped by the different data and information resulted in the study. This study may enable the people of all walks awaking of cultural hybridization. Social and cultural workers can get valuable information to formulate cultural policy and action plan.

An Important factor of change in any society is education that affects every thing of the world. In the development of Bhakkar, it has also played an important role and various fields of education humanities, science, fine arts, Technical education, Commerce and agriculture education determin socio, economic and political condition of the people. All the customs, traditions, way of living of past social contact of the people have undergone an obvious change and the economic position of the people has been also visibly improved, job opportunities created, new and modern methods are used in agriculture especially communication system saw amazing development due to education, it deeply influenced every walk of life and every segment of society and the people who graze animals round the clock and know nothing about the globaliztion facilities of life are now no more ignorant and their children are studying in good institutions. Their way of life has also been changed. The study may be useful for both the formal and informal researchers in advancement of new dimension. This study can be conducted on a large number of population.

\section{References}

Ali Shah. Mankera ka Adbi Manzar Nama. Multan, Sidq Ring Publishers, 2009, p.15.

Choudhary, K. Globalization, Governance Reforms and Development: An Introduction. In K. Choudhary (Ed.), Globalization, Governance Reforms and Development in India. New Delhi, Sage Publications, 2007.

Kraidy, M. M. Satellite television's Reinvigoration of Arab Polities Reality Television: Arab Politics. Contention in Public Life. London, Cambridge University Press, 2010.

Mishra, G. (2004). Globalization and culture. Online Journal of Radical Ideas, available at: http// iis-db.stanford.edu/pubs/23328/lifestyles.pdf.

Maliavin, V. V. (2012). Globalization and the Moral Issue, available at: http://tkugloba.tku.edu./ inglish/doc-c/Globalization.htm.

Shakeel Patafi. Nai Imkanat. Lahore, Sangat Publishers, 2010, p.123.

Tomlinson, J. Cultural Imperialism. Baltimore, John Hopkins University Press, 1991.

Tomlinson, J. Globalization and culture. Cambridge, 1999.

Yahya Ahmad. Affects of Persian Language on Seraiki. Peshawar, International Publishers, 1995, p. 174.

Yahya Ahmad. Farsi Zaban k Saraiki Par Asrat. Peshawar, Al-Huda Publishers, 1995, p.174. 


\title{
Культурная глобализация и ее влияние на студентов \\ в социально-экономически отсталом округе \\ Бхаккар в Пакистане в XXI веке
}

\author{
Сайед Рахим Аббас, Мухаммад Асим \\ ${ }^{a}$ Колледж Баккара \\ Пакистан \\ ${ }^{6}$ Колледж Асгар Молл, Равалпинди
}

Пакистан

\begin{abstract}
В настоящее время глобализачия затрагивает различные сферы жизни: экономическую деятельность, политическую сферу и т.д. Данная статья посвящена культурным изменениям, непосредственно влияющим на моральные ценности и образ жизни в Пакистане и, в частности, на студентов государственного колледжа Бхаккара и Университета Сардогха. В ходе исследования было выявлено доминирование западной культуры в жизни людей, которое приводит к исчезновению культурного наследия и моральных иенностей. Западная культура порождает консюмеризм, благодаря которому распространяется западньй образ жизни. Особой целью данного исследования было проанализировать, насколько быстро глобализачия трансформирует социальные обычаи и образ жизни в традиционных обществах среди студентов округа Бхаккара. Помимо негативных аспектов было также вылвлено положительное влияние процесса модернизации. В целом, большая часть данных была получена из двух вузов: государственного колледжа Бхаккара и кампуса Университета Сардогха в Бхаккаре. Результаты исследования будут полезны студентам Бхаккара для осознания культурной гибридизации в эру глобализации. Предполагается, что исследование внесет новые идеи, информачионный вклад в сочиальные науки.
\end{abstract}

Ключевые слова: культурная гибридизация, Бхаккар, западная культура, моральные ценности, образ жизни, разрушение, Макдональдс, культурное наследие.

Научная специальность: 23.00.00 - политология, 08.00.00 - экономические науки. 